\title{
Effect of Gender on Students' Achievement in Chemistry Using Inquiry Role Instructional Model
}

\author{
H.C. O. Aniodoh \\ Department of Science and Computer Education \\ Enugu State University of Science and Technology, Enugu-Nigeria \\ Joy Johnbest Egbo \\ Department of Chemistry, \\ Enugu State College of Education (Technical), Enugu-Nigeria
}

\section{Doi:10.5901/jesr.2013.v3n6p17}

\begin{abstract}
This study was designed to investigate the effect of inquiry role instructional model on students' achievement in chemistry. Two research questions and two null hypotheses were formulated to guide the study. It was conducted in public single sex secondary school in Enugu Education zone of Enugu state, Nigeria. Purposive sampling technique was used to select the four schools from the population of \{twenty-three\} 23 schools. A sample of 141 SS2 chemistry students was used. Researchers developed instrument, Chemistry Achievement Test (CAT) was used to collect data for both pretest and posttest. Mean and standard deviation scores were used to answer the research questions while analysis of covariance (ANCOVA) was used to test the hypotheses at alpha level of 0.05 . The findings showed that students taught with inquiry role instructional model achieved higher than those taught with expository method. It was also found that the female students performed better than their male counterparts when taught using inquiry role instructional model
\end{abstract}

Keywords: Inquiry-role, Chemistry Achievement Test, Team members, assigning roles

\section{Introduction}

Science plays a very important role in the development of any nation. Science is a way of thinking in pursuit of understanding nature, a way of investigating and a body of established knowledge (Aniodoh,2012). Science therefore is very crucial in shaping the way we think, explore, generate and apply knowledge about our environment. The importance of science in national development can hardly be over emphasized, for according to Ivowi,(2003)The development of a nation depends largely on the level of scientific and technological literacy possessed by the citizenry.

Chemistry is a branch of science which deals with the studies of the structure, composition, properties and reactions of matter in different forms. Chemistry is very important in the technological development of the nation. According to Asiyai (2005),

Chemistry has helped in the development of modern technology through the application of its principles in modern invention. The problem of students' persistent underachievement in chemistry is undoubtedly worrisome and has been a major concern to the researcher. Several studies have revealed unimpressive academic achievement in chemistry at the secondary school level in Nigeria. This problem, if not nipped in the bud, will have adverse consequences on the students and the 
society at large, given the importance of chemistry in Nigeria's scientific and technological development.

The West African Examination Council (WAEC), Chief examiners report(2006-2010) and a study by Eze and Egbo (2007) have attributed the observed student' poor achievement in chemistry to use of inappropriate and ineffective teaching method by chemistry teachers. Ebenebe and Unachukwu(1995) opined that the principle function of pedagogy is ensure that ideas and information are meaningfully presented, clear and retained over a long period of time. There is therefore, the need to explore innovative methods for effective teaching of chemistry so as to enhance students' achievement in the subject.

One of such innovative methods is the inquiry role instructional model which is a teaching method that is designed for small groups of students. Inquiry role instructional model has been found to enhance full participation of by team members, with each member being assigned a specific role. Each role has a set of related tasks assigned as the role responsibilities of the person who is performing the role. The roles are: Team coordinator, Technical advisor, Data recorder, Process advisor (Martin,2004). Team coordinator: coordinates team discussions and decision, clarifies team direction. Technical advisor: assists team coordinator in analyses, leads team in technical aspect of laboratory. Data recorder: records and directs recording of data and notes of team discussion; checks for consistency in records and between records. Process advisor: leads team in analysis of team interaction, identification of strengths and weaknesses, planning actions to improve team work.

Inquiry role instructional model has been found to be beneficial to students by giving them the opportunities to develop and use social and inquiry skills which enables them to participate as responsible members of the team (Bingman,1994).

The inquiry role has been found to be efficacious in fostering students' achievement in some school subjects, but there is paucity of research evidence on its use in chemistry teaching in Nigerian secondary school system.

Gender as a factor in science achievement has generated a lot of concern for science educators. Ocho a science educator (1997) observed that female students achieve better than male students in science. Ezeudu (1995) observed that sex has significant effect in favour of females in cognitive achievement. This shows that there is controversy on science achievement by gender .This underscore the need to investigate the effect of gender on students' achievement in chemistry using inquiry role instructional model.

The main purpose of the study is to determine the effect of inquiry role instructional model in teaching chemistry when compared with the expository method of instruction. The study specifically intended to: (1) determine the effect of inquiry role instructional model on students' achievement in chemistry

(2) ascertain the effect of inquiry role instructional model and expository method on male and female students' achievement in chemistry .

Research questions: The following research questions were posed to guide the study (1) what are the mean achievement scores of students taught chemistry using inquiry role instructional model and those taught by expository method of instruction

(2) what are the mean achievement scores of male and female students taught using inquiry role instructional model and expository method of instruction respectively as measured by Chemistry Achievement Test (CAT)

Hypotheses: Two null hypotheses tested at 0.05 level of significance guided the study

HO1 There is no significant difference in the mean achievement scores of SS2 chemistry students taught with inquiry role instructional model and those taught with expository method

HO2: There is on significant difference in the mean achievement scores in chemistry between male and female students taught with inquiry role instructional model as measured by Chemistry Achievement Test 


\section{Method}

The design of the study is quasi experimental; Research design. Specifically it is pre-test, nonequivalent control group design. The design was used because of non-randomization of subjects. The research subjects were not randomized because of problems of re-arrangement or re-grouping of intact classes. The population for the study consisted of all senior secondary class two (SS2) chemistry students who were offering chemistry in public single sex schools in Enugu Education Zone in the 2010 / 2011 session, numbering seven hundred and ninety-seven(797) (Statistics Units Post Primary Schools Management Board Enugu.) Single Sex schools were used to avoid gender interaction since gender is a factor in the study. The sample consisted of one hundred and forty one chemistry students. Simple random sampling technique was used to select two males and two females schools. In each of the sampled schools, all the SS2 chemistry students were used as research subjects. Chemistry Achievement Test (CAT) was used as instrument for the study. The instrument consisted of 40 multiple choice objective test developed by the researchers. The measuring instrument was based on chemistry content of qualitative analysis subdivided into preliminary tests, for cations and tests for anions.

\section{Procedures}

The regular chemistry teachers were used. The pre-test was administered to the experimental and control subjects before the teaching started. One hour was allowed for pretest, thereafter, the questions papers and the answer were collected from each student in both the experimental and control group. The reason for retrieving questions papers was that the same question will be used for the posttest. The posttest was administered to both the experimental and control subjects immediately after the three week of teaching. The pretest was reshuffled and printed on a coloured paper to give it a different look, before it was used for the posttest. The subject teachers did the supervision and invigilation.

\section{Results}

The results are presented according to the research questions and the hypotheses.

\subsection{Research question 1:}

What are the mean achievement scores of student's taught inquiry Role instructional model (RIM) and those taught using Expository method of instruction (EMI)

Table 1: Mean chemistry achievement score of student s taught using RIM and EMI

\begin{tabular}{|llllcr|}
\hline & \multicolumn{2}{c}{ Mean } & \multicolumn{3}{c|}{ Standard Deviation } \\
\hline Group & Pre-test & Post-test & Pre-test & Post-test & N \\
Experiment & 12.94 & 21.55 & 4.02 & 4.54 & 71 \\
Control & 12.59 & 11.31 & 3.91 & 3.38 & 70 \\
\hline
\end{tabular}

Table 1 indicates the means score of the experimental RIM group 12.94 and the standard deviation 4.02 are comparable to the mean score of the control EMI group 12.59 and standard deviation 3.91 during the pretesting whereas during the post-test, there seem to be an appreciable difference in the mean score of the experimental group is 21.55 and standard deviation 4.54 while that of the control group is 11.31 and standard deviation 3.38. This means that the treatments have a positive influence in the experimental group. 


\subsection{Research question 2:}

What are the mean achievement scores of male and female students taught chemistry using inquiry Role instructional model Expository method of instruction respectivel.

Table 2: Mean achievement scores of male and female students taught chemistry using IRM and EMI respectively.

\begin{tabular}{|lcccccc|}
\hline & \multicolumn{2}{c}{ Mean } & \multicolumn{3}{c|}{ Standard Deviation } \\
\hline Gender & Group & Pre-test & Post-test & Preset & Post-test & $\mathrm{N}$ \\
Male & Experiment & 12.10 & 21.40 & 4.49 & 4.78 & 30 \\
& Control & 12.35 & 11.67 & 4.09 & 3.44 & 34 \\
Female & Experiment & 13.56 & 21.66 & 3.56 & 4.40 & 41 \\
& Control & 12.81 & 10.97 & 3.77 & 3.33 & 36 \\
\hline
\end{tabular}

Table 2 shows that male student obtained a mean of 21.40 and female student has 21.66. The result in table 2 indicates that female group differed with male group in the mean achievement score in chemistry by 0.26 . The slight difference is in favour of the female subjects. $\mathrm{HO}_{2}$ where tested at 0.05 level of significance difference using two way analysis of covariance (ANCOVA) $\mathrm{Ho}_{1}$ :There is no significance difference in the mean achievement scores of SS2 chemistry students taught With IRIM and those taught with expository method of instruction.

$\mathrm{Ho}_{1}$ : There is no significant difference in the mean achievement scores in chemistry between male and female student taught chemistry with IRA as measured by chemistry Test (CAT)

Table 3: ANCOVA for student' mean achievement scores by instructional package types and gender.

\begin{tabular}{|lllcccc|}
\hline Source & $\begin{array}{l}\text { Sum of } \\
\text { Squares }\end{array}$ & Df & $\begin{array}{c}\text { Mean } \\
\text { Square }\end{array}$ & F & Significant & Decision \\
\hline Gender & 23.292 & 1 & 23.292 & 2.305 & .131 & NS \\
Method & 3570.127 & 1 & 3510.127 & 347.383 & .000 & S \\
Gender by & 939 & 1 & .939 & .093 & .761 & NS \\
$\begin{array}{l}\text { Method } \\
\text { Error }\end{array}$ & 1374.210 & 1 & 136 & $10.104 \mathrm{~s}$ & & \\
& & & & & \\
S = significant, NS = Not significant at 0.05 level of probability.
\end{tabular}

For hypothesis 1 table 3 showed that method was found significant at 0.000 which is less than 0.05 set for the study. Since the computed level of significant is less than the 0.05 set for the study. The researchers therefore conclude that there is a significant difference in the mean achievement scores of chemistry student taught with IRIM and those taught with EMI.

For hypothesis 2, table 3 showed that gender was significant at 0.31 which is greater than 0.05 set for the study. Since the computed level of Significance is greater than the 0.05 set for the study and in agreement With the decision rule. The researcher upholds the null hypothesis and concludes that there is no significant difference in the achievement scores of male and female students taught Chemistry with IRIM as measured by Chemistry Achievement Test (CAT).

\section{Conclusion}

Inquiry role instructional model was found more effective than expository method on Student's achievement in chemistry. Female chemistry students achieved higher than their male Counterparts. Chemistry teachers should be encouraged to employ the use of inquiry role 
instructional model more in the teaching of chemistry; by so doing, the achievement of the subject could be increased.

\section{References}

Aniodoh, H.C.O (2012). History and Philosophy of Science. Enugu:Hacofam Educational Books.

Asiyai, R.I. (2005).Enhancing chemistry teaching in secondary schools through concept mapping instructional strategy. Proceedings of the $46^{\text {th }}$ Annual Conference of science Teachers' Association of Nigeria. 205-209.

Bingman, R.M. (1994 ). Inquiry objective in the teaching of Biology, Mid Continent Regional Education laboratory Kansas City

Ebenebe, R.C. \& Unachukwu, G.C (1995). Psychology of learning Theories into Classroom practices. Onitsha: Onimax.

Eze, A.E \& Egbo, J.J (2007). Effect of concept Mapping method of instruction on students Achievement and retention in chemistry. Nigeria journal of functional Education 5 (1) 7 -11

Ezeudu, F O. (1995). Effect of concept map on students Achievement, interest and retention in selected unit on organic Chemistry Unpublished Ph.D Thesis, University of Nigeria, Nsukka.

I vowi, U.M.O. (2003). Achievement level in understanding science Concepts in Secondary school. Journal of Research in curriculum 1, $(2 \& 3) .241-525$.

Martin, F. (2004). Using an Inquiry approach to Teach Science to Secondary School Science Teacher. Kansas City.

Ocho, R.A. (1997) Gender valuation in science, Technology In G.A. Badmus and L. Ocho (eds) science,mathematics and technology in Nigeria. Lagos: Everleed Press. 
